\title{
SURFAKTAN UNTUK BAHAN BAKAR SOLAR DAN BIODIESEL
}

\section{SURFACTANT FOR THE DIESEL AND BIODIESEL FUELS}

\author{
Firda Dimawarnita ${ }^{1 * *}$ dan Erliza Hambali ${ }^{2)}$ \\ 1)Program Studi Pascasarjana Teknik Industri Pertanian, Institut Pertanian Bogor, Indonesia \\ ${ }^{2)}$ Departemen Teknologi Industri Pertanian, Fakultas Teknologi Pertanian, Institut Pertanian Bogor, Indonesia \\ J1. Raya Dramaga, Babakan, Dramaga, Bogor 16680, Indonesia \\ ${ }^{*}$ E-mail: dimawarnitafirda@apps.ipb.ac.id
}

Makalah: Diterima 21 Desember 2020; Diperbaiki 30 Juli 2021; Disetujui 10 Agustus 2021

\begin{abstract}
The government has determined that Indonesia is gradually implementing biodiesel as a substitute for fossil fuels. In September 2018 the B20 rule was established, then B30, and by the end of 2020 it became B50. That means 20\%, 30\%, and 50\% of fuel is biodiesel. Fatty acid methyl ester (FAME) known as biodiesel which is synthesized from palm oil produces a high yield, up to 95\%. However, in practice mixing FAME and diesel oil still has obstacles such as FAME will separate from diesel and form a gel, this is due to the hygroscopic nature of FAME and higher density of FAME compared to diesel oil. The decline in the quality of biodiesel is also caused by changes in some chemical and physical characteristics during storage. To overcome these problems, an emulsifier or surfactant solution is needed to homogenize the mixture of diesel fuel and biodiesel. Surfactants in biodiesel not only function as emulsifiers but also provide other added values, such as reducing hydrocarbons, $\mathrm{CO}, \mathrm{CO}_{2}$, and $\mathrm{NO}_{x}$ in exhaust gas emissions when compared to without surfactants. Some literature suggests that $35 \%$ reduction in hydrocarbon emissions occurs when Jatropha methyl ester has been mixed with surfactant and nano carbon compared to Jatropha methyl ester alone. The use of nano additives also showed differences in the stability of biodiesel and surfactants, the addition of nano additives in the form of nano carbon and nano cerium increased the stability and homogeneity of biodiesel for longer. Thus, biodiesel can be stable for a certain period of time. This review will show the various types of emulsifiers used in fuel mixing and the time of stability formed.
\end{abstract}

Keywords: biodiesel, emulsifer, homogenization, palm oil, diesel fuel

\begin{abstract}
ABSTRAK
Pemerintah telah menetapkan bahwa Indonesia secara bertahap menerapkan biodiesel sebagai pengganti bahan bakar fosil. Pada bulan September 2018 telah menetapkan aturan B20, kemudian B30, dan akhir 2020 menjadi B50. Hal tersebut berarti 20\%, 30\%, dan 50\% bahan bakar merupakan biodiesel dan sisanya adalah solar. Fatty Acid Methyl Etser (FAME) yang dapat disintesis dari minyak kelapa sawit menghasilkan yield yang cukup tinggi, mencapai 95\%. Namun, dalam prakteknya pencampuran FAME dan solar masih terdapat kendala diantaranya: FAME akan terpisah dengan solar dan membentuk gel, hal ini disebabkan karena sifat FAME yang higroskopis dan massa jenis FAME yang lebih tinggi dibandingkan solar. Penurunan kualitas biodiesel juga disebabkan oleh perubahan beberapa karakteristik fisika kimia selama penyimpanan. Untuk mengatasi permasalahan tersebut, diperlukan solusi berupa emulsifier/surfaktan untuk menghomogenkan campuran bahan bakar solar dan biodiesel (biosolar). Surfaktan dalam biodiesel tidak hanya berfungsi sebagai emulsifier tapi juga memberikan nilai tambah lain, seperti menurunkan hidrokarbon, $\mathrm{CO}, \mathrm{CO}_{2}$, dan $\mathrm{NO}_{\mathrm{x}}$ pada emisi gas buang jika dibandingkan dengan tidak menggunakan surfaktan. Beberapa literatur mengemukakan bahwa 35\% penurunan emisi hidrokarbon terjadi ketika Jatropha methyl ester telah dicampur surfaktan dan nano karbon dibandingkan dengan Jatropha methyl ester saja. Penggunaan nano aditif juga menunjukkan adanya perbedaan stabilitas biodiesel dan surfaktan, pemberian nano aditif berupa nano carbon dan nano cerium meningkatkan stabilitas dan homogenitas biodiesel menjadi lebih lama. Dengan demikian, biosolar dapat stabil dalam jangka waktu tertentu. Review ini akan menampilkan berbagai jenis emulsifier yang digunakan dalam pencampuran bahan bakar dan waktu stabilitas yang terbentuk.
\end{abstract}

Kata kunci: biodiesel, homogenisasi, surfaktan, sawit, solar

\section{PENDAHULUAN}

Kebutuhan akan energi sampai saat ini terus mengalami peningkatan, sedangkan ketersediaan energi berbahan bakar fosil semakin hari semakin menurun. Pemerintah melalui Peraturan Menteri
ESDM tahun 2018 No.41 telah menetapkan bahwa Indonesia akan secara bertahap menerapkan biodiesel sebagai pengganti bahan bakar fosil. Pada bulan September 2018 telah menetapkan aturan B20, awal 2020 beralih ke B30, kemudian akhir 2020 menjadi B50. Hal tersebut berarti $20 \%$, 30\%, dan $50 \%$ nya

*Penulis Korespodensi 
merupakan biodiesel dan sisanya adalah solar. Penggunaan bahan bakar berbasis fosil tidak hanya menimbulkan kelangkaan yang semakin meningkat melainkan juga dampak terhadap lingkungan yang buruk, diantaranya peningkatan suhu permukaan bumi (global warming), perubahan iklim dan cuaca (Reham et al., 2015; Ramakrishnan et al., 2019; Bhimani et al., 2013; Elsanusi et al., 2017)

Saat ini, bahan bakar alternatif paling populer di dunia adalah biodiesel (Radhakrishnan et al., 2018, Melo-Espinosa et al., 2015), green gasolin (Joensen et al., 2011), dan biosyngas (Reham et al., 2015). Pengembangan dan penelitian energi terbarukan tersebut sekarang ini sedang menjadi tren dan terus dilakukan, karena bioenergi memiliki kelebihan dibandingkan bahan bakar fosil. Sebagai contoh, hasil emisi dari pembakaran biodiesel lebih bersih jika dibandingkan pembakaran bahan bakar yang berasal dari fosil. Pembakaran biodiesel dapat mengurangi emisi dari karbon monoksida (CO), total hidrokarbon (THC), particulate matter (PM), dan poliakromatik hidrokarbon $(\mathrm{PAH})$, namun emisi dari gas nitrogen oksida (NOx) masih tinggi (Sadhik Basha, 2018; Sadhik Basha dan Anand, 2014; Vellaiyan, 2020; Vellaiyan et al., 2018; Vellaiyan et al., 2019). Sehingga, penggunaan biodiesel merupakan solusi yang ramah lingkungan. Biodiesel dapat disintesis dari berbagai macam tumbuhan seperti kelapa sawit (Hambali dan Nuryanti, 2016), nyamplung (Trisunaryanti et al., 2019), jarak pagar (Sadhik Basha dan Anand, 2014), minyak kelapa (Qiu et al., 2016), minyak kedelai (Xie dan Wang, 2014), minyak biji bunga matahari (Mahmudul et al., 2017). Namun, biodiesel di Indonesia kelapa sawit untuk menghasilkan fatty acid methyl ester (FAME). Sejauh ini FAME dari minyak kelapa sawit merupakan sumber biomassa yang melimpah dan produktivitas cukup tinggi, sehingga paling feasible untuk diproduksi menjadi biodiesel di Indonesia.

FAME yang dapat disintesis dari minyak kelapa sawit menghasilkan yield yang cukup tinggi, mencapai 95\% (El-Araby et al., 2018; Wang et al., 2017). Namun, dalam prakteknya pencampuran FAME dan solar tidaklah mudah, pada kenyataannya masih banyak kendala diantaranya: FAME akan terpisah dengan solar dan membentuk gel pada saat di suhu rendah hal ini disebabkan karena sifat FAME yang higroskopis (Melo-Espinosa et al., 2015); massa jenis FAME lebih tinggi dibandingkan solar (Bezergianni dan Dimitriadis, 2013), serta proses pembakaran kurang sempurna karena keberadaan air menyebabkan ampas atau kerak pada pipa mesin kendaraan bermotor (Sheriff et al., 2020). Penurunan kualitas biodiesel juga dapat disebabkan oleh perubahan beberapa karakteristik fisika kimia selama penyimpanan. Penyebab utamanya adalah adanya oksigen terlarut yang menyebabkan terjadinya reaksi antara metil ester dengan sisa gliserol, baik mono maupun di-gliserida yang tersisa dalam FAME membentuk alkohol, aldehid, keton, asam karboksilat serta endapan. Hal tersebut juga dapat terjadi karena bereaksinya hidrolisa metil ester dengan air terlarut yang menyebabkan meningkatnya bilangan asam. Hal tersebut membuat potensi filter mesin cepat tersumbat dan pembakaran pada mesin kendaraan bermotor tidak sempurna; akibatnya kendaraan bermotor memerlukan perawatan yang ekstra. Untuk mengatasi permasalahan tersebut, diperlukan solusi berupa emulsifier/surfaktan untuk menghomogenkan campuran bahan bakar solar dan biodiesel (biosolar). Sehingga, biosolar dapat stabil dalam jangka waktu tertentu sehingga biodiesel tidak terpisah dengan solar.

Penambahan surfaktan dalam bahan bakar biodiesel memiliki fungsi sebagai emulsifier, menurunkan emisi gas hidrokarbon, $\mathrm{CO}, \mathrm{CO}_{2}$, dan NOx (Sadhik Basha, 2018; Sadhik Basha \& Anand, 2014). Berdasarkan penelitian Basha dan Anand (2014) penurunan emisi hidrokarbon sebanyak $35 \%$ dapat dicapai ketika Jatropha methyl ester telah dicampur surfaktan dan nano karbon. Begitu juga dengan penelitian yang telah dilakukan Raheman dan Sweetie (2014) yang juga menunjukkan penambahan surfaktan pada biodiesel minyak jarak menghasilkan gas emisi yang lebih bersih dibandingkan dengan biodiesel tanpa penambahan surfaktan. Selain itu, penambahan nano aditif seperti nano karbon dan nano cerium (Sadhik Basha, 2018; Annamalai et al., 2016; Khalife et al., 2017) menunjukkan adanya perbedaan stabilitas biodiesel. Pemberian nano aditif dapat meningkatkan stabilitas dan homogenitas biodiesel menjadi lebih lama dan stabil. Review ini akan membahas berbagai jenis surfaktan/emulsifier yang digunakan dalam pencampuran bahan bakar dan waktu stabilitas yang terbentuk.

\section{METODE PENELITIAN}

Metode yang digunakan dalam review ini adalah mencari literatur terkait yang berhubungan dengan stabilitas biodiesel dan emulsifier/surfaktan yang digunakan dalam bahan bakar biodesel. Hasil literatur yang didapat direview dan ditelaah sehingga dapat disimpulkan.

\section{HASIL DAN PEMBAHASAN}

\section{Biofuel Teremulsi}

Biofuel teremulsi adalah penambahan emulsifier atau surfaktan dengan tujuan menghomogenkan larutan (biofuel) sehingga larutan stabil. Selama ini biofuel, khususnya biodiesel masih sensitif terhadap suhu rendah (Kegl, 2008). Adanya FAME dalam biodiesel menyebabkan biodiesel bersifat higroskopis sehingga dalam waktu tertentu terdapat air dalam tangki penyimpanan biodiesel. Bahkan pada suhu tertentu akan membentuk gel. Surfaktan merupakan zat perantara antara larutan 
heterogen makroskopik dan larutan molekuler yang merupakan sistem homogen. Surfaktan dapat digunakan sebagai agen emulsifier untuk melakukan homogenisasi biofuel dan air melalui dua cara, yaitu: dispersi makroskopis dan kondensasi larutan (MeloEspinosa et al., 2015).

Biodiesel teremulsi merupakan sistem yang terdispersi dan dapat didefinisikan sebagai campuran dua larutan atau lebih, yang setidaknya memiliki satu fase yang tidak larut (seperti air dan minyak) dan dapat terdispersi menjadi yang lain. Biodiesel teremulsi banyak digunakan sebagai bahan bakar mesin dengan sistem terdispersi dari jenis water in oil (W/O). Air berperan sebagai fase terdispersi yang tersebar dalam minyak atau lemak (fase kontinu). Dalam pembahasan biodiesel teremulsi, perlu dibedakan istilah emulsi dan mikroemulsi. Terdapat perbedaan yang signifikan antara keduanya meskipun sama-sama sistem yang terdispersi. Emulsi dan mikroemulsi berbeda tidak hanya dalam ukuran dari fase terdispersi, tetapi juga dalam hal stabilitas termodinamikanya (Ochoterena et al., 2010).

Sebagian besar karakteristik emulsi (stabilitas, viskositas, dll.) tergantung pada ukuran fase terdispersi dan distribusi ukuran. Emulsi memiliki stabilitas tertentu yang meningkat seiring penggunaan agen pengemulsi; emulsi secara termodinamik tidak stabil dan membutuhkan energi. Ketidakstabilan tersebut dikarenakan adanya energi bebas Gibbs ( $\Delta \mathrm{Gf})$ yang positif $(\Delta \mathrm{Gf}>0)$. Keberadaan energi bebas Gibbs akan mempengaruhi tegangan permukaan suatu larutan. Pengurangan energi bebas Gibbs dapat menghasilkan emulsi yang lebih stabil karena tegangan permukaan akan berkurang dan berukuran lebih kecil yang dikelilingi lapisan tunggal, sehingga mencegah terjadinya flokulasi. Oleh karena itu, emulsi memiliki kecenderungan spontan untuk pemisahan fase. Ukuran fase terdispersi biasanya antara 1-10 mm dan sebagian besar emulsi memiliki visualisasi warna buram dan warna putih susu (Yang et al., 2013).
Emulsi adalah sistem yang secara termodinamik tidak stabil dan diharapkan terjadi proses pemecahan molekul sehingga emulsi dapat berikatan dengan fase minyak dan fase air dari larutan yang diberikan emulsifier. Secara konsep proses pemecahan emulsi adalah proses bertingkat, yang melibatkan fenomena fisik seperti pengendapan secara gravitasi, penurunan area antarmuka dan energi bebas dari sistem. Perbedaan proses pemecahan pada sistem terdispersi ditunjukkan pada Gambar 1.

Fenomena fisik yang terlibat dalam setiap proses penggabungan molekul tidak sederhana dan memerlukan analisis berbagai energi yang terlibat dalam proses tersebut (Tadros, 2013). Fenomena yang terjadi pada emulsi, berbeda dengan mikroemulsi. Mikroemulsi adalah sistem yang terbentuk secara spontan yang kemudian memiliki struktur terdispersi dalam bentuk mikro. Mikroemulsi spontan terbentuk ketika rasio surfaktan, kosurfaktan, dan minyak lebih dari 1 (Yang et al., 2013). Mikroemulsi memiliki karakteristik khusus, seperti: stabil secara termodinamik, memiliki energi bebas yang rendah (negatif atau nol), tegangan antarmuka rendah $\left(10^{-3}-10^{-4} \mathrm{mN} / \mathrm{m}\right)$ dan secara visual memiliki warna yang transparan (Neto et al., 2011). Energi bebas Gibbs dari mikroemulsi negatif atau nol $(\Delta \mathrm{Gf} \leq$ $0)$. Hal tersebut menunjukkan mikroemulsi memiliki ukuran tetes yang jauh lebih kecil daripada emulsi. Umumnya ukuran mikroemulsi berada di kisaran 0,001-0,15 mm. Ini sesuai dengan (!!! Invalid Citation !!! ) yang melaporkan ukuran kisaran tetes dalam mikroemulsi berada di ukuran 0,005-0,02 mm.

\section{Efek Air Pada Biofuel Teremulsi}

Salah satu komponen penting yang digunakan untuk menghomogenkan bahan bakar teremulsi adalah air. Efek negatif keberadaan air dalam bahan bakar dapat merusak kendaraan karena menyebabkan oksidasi dan terbentuknya karat pada mesin kendaraan.

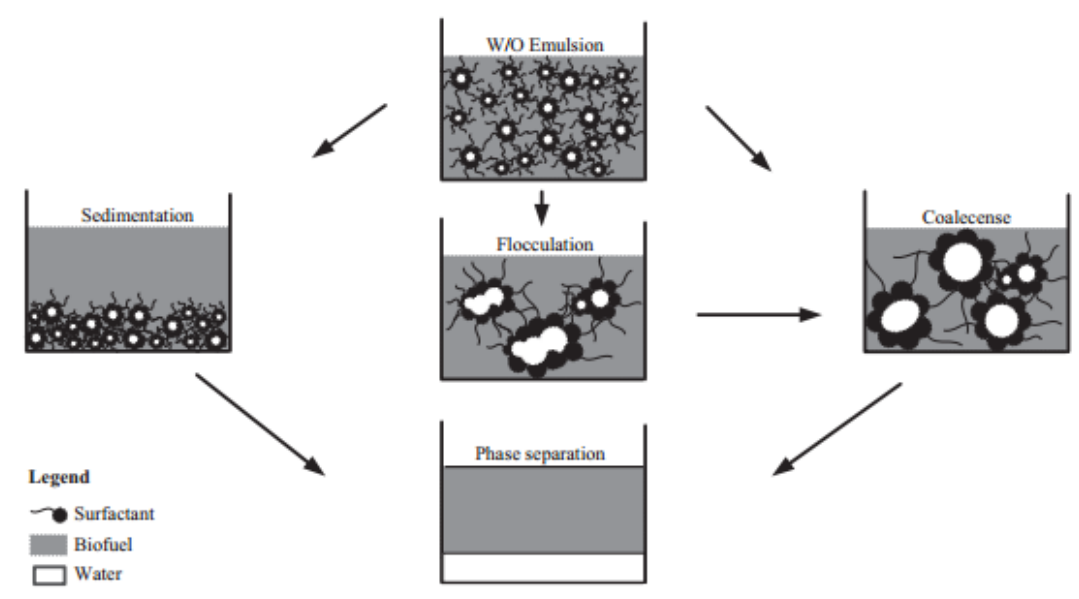

Gambar 1. Proses pemecahan emulsi pada water in oil (W/O) 
Mesin kendaraan memerlukan perhatian khusus berkaitan dengan stabilitas bahan bakar yang diemulsi. Kehadiran air dalam bahan bakar dapat menyebabkan pembentukan karat, menyebabkan kondisi asam, dan hidroperoksida yang terbentuk karena oksidasi bahan bakar, sehingga dapat menyebabkan korosi (Vellaiyan et al., 2018).

Garam $(\mathrm{NaCl})$ yang secara alami ada dalam air dapat mempengaruhi fungsi agen pengemulsi dan sifat bahan bakar yang diemulsi (stabilitas). Efek senyawa anorganik pada sistem terdispersi distabilkan oleh berbagai jenis surfaktan (!!! Invalid Citation !!! ). Hasil yang dicapai oleh Balcan et al., 2014 menunjukkan bahwa elektrolit (5 ppm berat $\mathrm{NaCl}$ dalam air) kurang efektif dalam sistem yang mengandung surfaktan teretoksilasi. Ketika jumlah $\mathrm{NaCl}$ meningkat, ion garam bersaing dengan surfaktan untuk berikatan dengan air dan interaksi antara surfaktan dan air menurun. Namun, ketika interaksi hidrofilik dan hidrofobik pada antarmuka minyak/air seimbang, surfaktan mempu melarutkan minyak dan air dalam jumlah besar dan kontinu. Oleh sebab itu, pemilihan surfaktan dan kosurfaktan harus tepat karena adanya kandungan garam dalam air pada beberapa kasus yang menyebabkan surfaktan tidak bekerja dengan baik. Pemilihan surfaktan yang tepat sangat diperlukan untuk meningkatkan sistem emulsi yang terdispersi.

Penelitian (Fayyad et al., 2010) merekomendasikan penggunaan air demineralisasi karena air demineralisasi memberikan stabilitas yang lebih baik untuk emulsi water in oil (W/O) daripada air kran/air biasa. Air dalam biodiesel teremulsi sebaiknya tidak digunakan mengganti jumlah bahan bakar tertentu untuk menghemat bahan bakar. Tujuan dari air adalah untuk mengoptimalkan massa pembakaran bahan bakar dengan lebih baik, meningkatkan proses atomisasi di dalam silinder mesin sebelum proses pembakaran terjadi. Keberadaan air pada biodiesel teremulsi mengurangi nilai pemanasan bahan bakar dan menurunkan total energi per unit massa bahan bakar.

\section{Formulasi Emulsifier untuk Biodiesel}

Metodologi yang akurat untuk formulasi emulsifier untuk biofuel tergantung pada jenis bahan baku yang digunakan (minyak nabati/lemak hewani/zat pengemulsi) dan metode tersebut preparasi yang berbeda (metode mekanis dan fisikkimia) seperti pengaduk mekanis yang digunakan (Reyes dan Charcosset, 2010). Diantara berbagai metode terebut, metode dispersi paling banyak diterapkan. Hal ini karena metode dispersi memiliki kelebihan diantaranya dapat menghasilkan ukuran tetesan yang kecil, sehingga mencegah terjadinya flokulasi dan memungkinkan sistem untuk tersebar tanpa adanya pemisahan. Teknik getaran ultrasonik diklaim sebagai pilihan yang sangat baik yang secara efektif mampu membuat partikel kecil dalam larutan di kecepatan tinggi (Kannan dan Anand, 2011). Semakin tinggi kecepatan rotasi akan mampu memecah zat yang diemulsi menjadi molekul yang lebih kecil. Namun, kecepatan rotasi sebaiknya dilakukan diatas $1500 \mathrm{rpm}$, karena pemecahan ukuran dalam larutan teremulsi tidak terjadi jika kecepatan rotasi pengaduk dalam rentang 500-1500 rpm (Kerihue et al., 2006).

Sebagian besar karakteristik biodiesel yang diemulsi dapat diperbaiki dengan memperhitungkan berbagai faktor selama proses persiapan, seperti: karakteristik surfaktan dan co-surfaktan (Balcan et al., 2014), intensitas dan durasi metode yang digunakan (Elsanusi et al., 2017), rasio volume(Fresneda et al., 2020) dan sifat fisik (viskositas dan tegangan permukaan) dari masingmasing fase (Kumar et al., 2020), dan pemanasan minyak nabati (Melo-Espinosa et al., 2015). Balcan et al. 2014 menunjukkan bahwa pada suhu ruang, air adalah pelarut yang lebih baik daripada minyak untuk surfaktan nonionik, tetapi pada suhu tinggi merupakan pelarut yang buruk. Namun, hal tersebut berlaku sebaliknya untuk surfaktan ionik.

Tujuan penambahan surfaktan adalah untuk mengurangi tegangan permukaan minyak dan air, mengaktifkan permukaannya dan memaksimalkan kontak area permukaan untuk mendapatkan emulsi atau mikroemulsi yang membentuk fase tetesan kontinu tersebar halus (Kerihue et al., 2006). Hal tersebut merupakan kemampuan surfaktan untuk menstabilkan sistem terdispersi (mikroemulsi atau emulsi) yang ditentukan oleh struktur molekul surfaktan dan energi interaksinya dengan sistem (polar dan nonpolar). Surfaktan berorientasi dengan cara gugus hidrofilik berikatan dengan air dan gugus hidrofobik berikatan dengan minyak (Fresneda et al., 2020; Ramakrishnan et al., 2019; Melo-Espinosa et al., 2015). Surfaktan yang digunakan oleh peneliti pada biofuel dapat dilihat dalam Tabel 1 .

Kerihue et al. 2006 menunjukkan bahwa surfaktan yang dipilih untuk memformulasikan biofuel emulsi harus lebih larut dalam minyak (fase berkelanjutan) untuk mendapatkan biofuel yang memiliki emulsi stabil. Pemilihan surfaktan dapat dilihat dari jumlah HLB yang sesuai dengan keseimbangan hidrofilik-lipofilik. Menurut (Debnath et al., 2013) HLB adalah nilai non-dimensi, mulai dari 0 hingga 20. Molekul hidrofilik adalah molekul yang berinteraksi dengan air atau larut dalam air dan zat polar lainnya; sedangkan molekul lipofilik larut dalam lemak, minyak, lipid, dan pelarut non-polar. Surfaktan yang digunakan untuk formulasi sistem terdispersi harus dipilih sesuai HLB nya, dan untuk sistem W/O penggunaan surfaktan sebaiknya dipilih yang lebih lipofilik daripada hidrofilik. Berdasarkan Tebal 1, pemilihan surfaktan berdasarkan jenis HLB bertujuan untuk melihat stabilitas biodiesel pada berbagai jenis surfaktan (surfaktan larut dalam air maupun minyak). 
Tabel 1. Surfactans used for emulsifier formulations of biofuel

\begin{tabular}{|c|c|c|c|}
\hline Jenis surfaktan & Struktur kimia & HLB & Referensi \\
\hline $\begin{array}{l}\text { Sorbitan monopalmitat } \\
\text { (Span 40) }\end{array}$ & $\mathrm{C}_{22} \mathrm{H}_{42} \mathrm{O}_{6}$ & 6,7 & (Satapathy et al., 2013) \\
\hline Sorbitan monostearat (Span 60) & $\mathrm{C}_{22} \mathrm{H}_{46} \mathrm{O}_{6}$ & 4,7 & (Melo-Espinosa et al., 2015) \\
\hline Sorbitan monooleat (Span 80) & $\mathrm{C}_{24} \mathrm{H}_{44} \mathrm{O}_{6}$ & 4,3 & (Sadhik Basha, 2018) \\
\hline Sorbitan sesquiolat (Span 83) & $\mathrm{C}_{66} \mathrm{H}_{130} \mathrm{O}_{18}$ & 3,7 & (Mura et al., 2012) \\
\hline Sorbiton trioleat (Span 85) & $\mathrm{C}_{60} \mathrm{H}_{108} \mathrm{O}_{8}$ & 1,8 & (Vivek et al., 2014) \\
\hline $\begin{array}{l}\text { Polioksietilen sorbitan monooleat } \\
\text { (Tween 80) }\end{array}$ & $\mathrm{C}_{64} \mathrm{H}_{124} \mathrm{O}_{26}$ & 15,0 & $\begin{array}{l}\text { (Phasukarratchai, 2019, Sadhik Basha } \\
\text { \& Anand, 2011) }\end{array}$ \\
\hline Polisorbat (Tween 20) & $\mathrm{C}_{58} \mathrm{H}_{114} \mathrm{O}_{26}$ & 16,7 & (Phasukarratchai, 2019) \\
\hline Tetraetilen glikol dodesil eter (Brij 30) & $\mathrm{C}_{20} \mathrm{H}_{42} \mathrm{O}_{5}$ & 9,7 & (!!! INVALID CITATION !!! ) \\
\hline $\begin{array}{l}\text { Sodium bis-(2-etileksil) sulfosusunat } \\
\text { (AOT) }\end{array}$ & $\mathrm{C}_{20} \mathrm{H}_{37} \mathrm{O}_{7} \mathrm{SNa}$ & 10,2 & (Balcan et al., 2014) \\
\hline Asam oleat & $\mathrm{C}_{18} \mathrm{H}_{34} \mathrm{O}_{2}$ & 1,0 & (Qi et al., 2013) \\
\hline
\end{tabular}

Debnath et al. 2013 merekomendasikan bahwa angka HLB harus berada diantara 4 dan 6 untuk sistem air-dalam-minyak. Bhimani et al., 2013 mengindikasikan adanya campuran surfaktan hidrofilik dan hidrofobik menghasilkan larutan emulsi yang lebih stabil dengan nilai HLB 4,6. Oleh sebab itu, untuk memperoleh campuran surfaktan dengan nilai HLB yang sesuai dapat digunakan persamaan matematika untuk menghitungnya (Bhimani et al., 2013). Melalui persamaan ini persentase massa dari surfaktan yang terlibat dalam campuran dapat diperoleh.

$$
\% A=\frac{\left[100 x\left(X-H L B_{B}\right)\right]}{\left(H L B_{A}-H L B_{B}\right)}
$$

\section{Aplikasi Emulsifier untuk Biodiesel}

Pembuatan formulasi surfaktan untuk biodiesel telah dilakukan oleh beberapa peneliti, diantaranya menggunakan bahan baku berupa minyak jarak, minyak kedelai, minyak biji bunga matahari, minyak jelantah, minyak sawit, dan minyak canola (Tabel 2). Penambahan surfaktan dapat meningkatkan stabilitas biodiesel yang dihasilkan. Stabilitas biodiesel bertambah dari 20 menit menjadi 4 minggu. Hal ini akan berpengaruh pada performa bahan bakar yang dihasilkan. Berdasarkan penelitian Sadhik Basha, 2018 penambahan surfaktan pada bahan bakar dapat mengurangi emisi gas buang pada mesin kendaraan. Performa pembakaranpun juga akan semakin meningkat dengan penambahan surfaktan yang sesuai. Pemilihan jenis aditif yang ditambahkan juga akan mempengaruhi stabilitas bahan bakar yang terbentuk. Aditif berupa surfaktan seperti span80, etanol, dietil eter (DEE) membuat stabilitas bahan bakar bertahan lebih lama sampai 4 minggu. Hal ini karena surfaktan tersebut memiliki nilai HLB 4-6 yang memiliki kecenderungan larut dalam minyak.

Selain surfaktan, nano aditif juga dapat digunakan sebagai aditif bahan bakar. Penambahan nano aditif sebanyak 50 ppm berupa nano karbon maupun nano cerium pada surfaktan akan menambah stabilitas biodiesel. Penggunaan nano aditif seperti carbon nano tube (CNT) (Sadhik Basha, 2018), nano cerium oksida (Annamalai et al., 2016; Sheriff et al., 2020; Khalife et al., 2017) menunjukkan adanya peningkatan stabilitas biodiesel diatas 8 hari. Selain itu, gas emisi yang dihasilkan seperti gas $\mathrm{CO}, \mathrm{NOx}$, dan hidrokarbon juga berkurang sebesar 10-35\% dibandingkan tanpa penambahan nano aditif. Performa mesin lebih baik dibandingkan tanpa nano aditif. Pada penambahan 90 ppm nano cerium oksida pada biodiesel menurunkan konsumsi bahan bakar sebesar 5\% dan meningkatkan brake thermal efficiency sebesar 11\% (Khalife et al., 2017). Penambahan diethyl eter (DEE) ataupun gliserol ester (Sri Wahyuni, 2016) meningkatkan efisiensi pembakaran biodiesel. Penambahan DEE sebanyak $2 \%$ meningkatkan brake thermal efficiency sebesar $10 \%$, dan emisi gas NOx, CO, hidrokarbon, dan asap berkurang sebesar 30\% (Dinesha et al., 2019).

Penambahan surfaktan sebagai aditif bahan bakar merupakan salah satu alternatif untuk meningkatkan performa bahan bakar, khususnya dalam hal stabilitas bahan bakar. Surfaktan dengan nilai HLB rendah memiliki kemampuan yang baik untuk stabilitas bahan bakar dan pembakaran pada mesin. Selain itu, penambahan nano aditif juga memiliki peran penting untuk mengurangi emisi gas yang dihasilkan biodiesel. Studi literatur dan penelitian mengenai emulsifier untuk biodiesel harus diperbanyak dan mulai dilakukan oleh negara-negara seperti Indonesia yang memiliki biomassa yang cukup banyak untuk dikembangkan menjadi biodiesel. Seperti kelapa sawit, yang merupakan bahan baku biodiesel di Indonesia. Pelitian mengenai emulsifier sebagai aditif biodiesel untuk menghomogenkan bahan bakar solar dan diesel dari minyak kelapa sawit perlu diperkuat karena secara aplikasi Indonesia telah menerapkan B30 dan akan terus meningkat. Permasalahan-permasalahan yang muncul pada biodiesel berbasis minyak sawit saat ini harus segera teratasi sehingga dapat turut mensukseskan program pemerintah. 
Tabel 2. Penelitian aplikasi surfaktan pada biodiesel

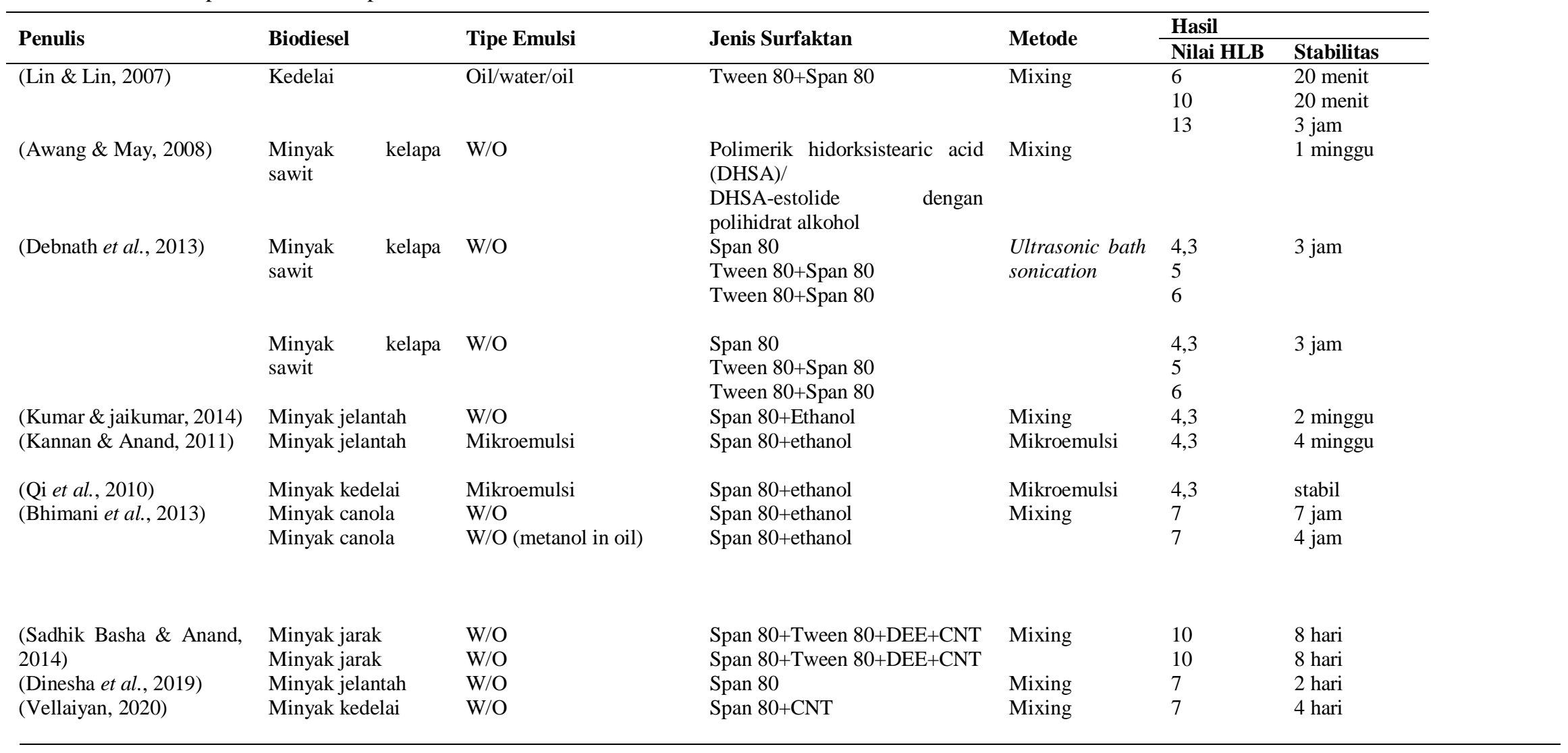




\section{KESIMPULAN DAN SARAN}

Penambahan surfaktan sebagai aditif bahan bakar merupakan salah satu alternatif untuk meningkatkan performa bahan bakar, khususnya dalam hal stabilitas bahan bakar. Surfaktan dengan nilai HLB rendah memiliki kemampuan yang baik untuk stabilitas bahan bakar dan pembakaran pada mesin. Selain itu, penambahan nano aditif juga memiliki peran penting untuk mengurangi emisi gas yang dihasilkan biodiesel. Studi literatur dan penelitian mengenai emulsifier untuk biodiesel harus diperbanyak dan mulai dilakukan oleh negara-negara seperti Indonesia yang memiliki biomassa yang cukup banyak untuk dikembangkan menjadi biodiesel. Seperti kelapa sawit, yang merupakan bahan baku biodiesel di Indonesia. Pelitian mengenai emulsifier sebagai aditif biodiesel untuk menghomogenkan bahan bakar solar dan diesel dari minyak kelapa sawit perlu diperkuat karena secara aplikasi Indonesia telah menerapkan B30 dan akan terus meningkat. Permasalahan-permasalahan yang muncul pada biodiesel berbasis minyak sawit saat ini harus segera teratasi sehingga dapat turut mensukseskan program pemerintah.

\section{UCAPAN TERIMA KASIH}

Terima kasih diucapkan kepada Dosen Teknik Mesin UI, Prof. Bambang Sugiarto dan Dosen Teknik Mesin ITB, Dr. Tri Yuswidjajanto Zaenal yang telah berpartisipasi dalam proses diskusi mengenai emulsifier untuk solar dan biodiesel ini. Sehingga artikel ini dapat selesai ditulis.

\section{DAFTAR PUSTAKA}

Annamalai M, Dhinesh B, Nanthagopal K, SivaramaKrishnan P, J Isaac JoshuaRamesh Lalvani, Parthasarathy M, Annamalai K. 2016. An assessment on performance, combustion and emission behavior of a diesel engine powered by ceria nanoparticle blended emulsified biofuel. Energy Conversion and Management. 123: 372-380.

Awang R dan May CY. 2008. Water in oil emulsion of palm biodiesel. Journal Oil Palm Research. 20: 571-576.

Balcan M, F-CM ilescu, D-F Anghel, I-CtlVcr teanu, L Aricov \& E-L Vasilescu. 2014. Microemulsion systems containing diesel and colza oil as alternative fuels: Phase studies, interfacial tension and solubilization. Fuel. 117: 251-258.

Bezergianni S dan Dimitriadis A. 2013. Comparison between different types of renewable diesel. Renewable and Sustainable Energy Reviews. 21: 110-116.

Bhimani S, Alvarado JL, Annamalai K Marsh C. 2013. Emission characteristics of methanol- in-canola oil emulsions in a combustion chamber. Fuel. 113: 97-106.

Debnath BK, Sahoo N, dan Saha UK. 2013. Adjusting the operating characteristics to improve the performance of an emulsified palm oil methyl ester run diesel engine. Energy Conversion and Management. 69: 191-198.

Dinesha P, Kumar S, dan Rosen MA. 2019. Combined effects of water emulsion and diethyl ether additive on combustion performance and emissions of a compression ignition engine using biodiesel blends. Energy. 179: 928-937.

El-Araby R, Amin A, El Morsi AK, El-Ibiari NN, GI El-Diwani. 2018. Study on the characteristics of palm oil-biodiesel-diesel fuel blend. Egyptian Journal of Petroleum. 27(2): 187-194.

Elsanusi OA, Roy MM dan Sidhu MS. 2017. Experimental Investigation on a Diesel Engine Fueled by Diesel-Biodiesel Blends and their Emulsions at Various Engine Operating Conditions. Applied Energy. 203: $582-593$

Fayyad SM, Abu-Ein S, Al-Marahleh G, WaA-M omani, Al-Momani M, Abulghanam Z, Badran O, Abu-Rahmah T. 2010. Experimental Emulsified Diesel and Benzen Investigation. Research Journal of Applied Science, Engineering and Technology. 2 (3): 268-273.

Fresneda M, Trujillo-Cayado LA, García MC, Alfaro-Rodriguez MC, Muñoz J. 2020. Production of more sustainable emulsions formulated with eco-friendly materials. Journal Cleaner Production. 243: 118-126.

Hambali dan Nuryanti. 2016. Potential of Biomass as Bioenergy Feedstock in Indonesia. Journal of the japan institute of energy. 95: 629-638.

Joensen F, Nielsen PEH, dan Palis Sørensen MD. 2011. Biomass to green gasoline and power. Biomass Conversion and Biorefinery. 1(2): 85-90.

Kannan GR dan Anand R. 2011. Experimental investigation on diesel engine with diestrolewater micro emulsions. Energy. 36: 1680-1687.

Kegl B. 2008. Biodiesel usage at low temperature. Fuel. 87(7): 1306-1317.

Kerihue A, Kumar MS, Bellettre J, Tazerout M. 2006. Ethanol animal fat emulsions as a diesel engine fuel - Part 1: Formulations and influential parameters. Fuel. 85: 2640-2645.

Khalife E, Tabatabaei M, Najafi B, Mirsalim SM, Gharehghani A, Mohammadi P, Aghbashlo M, Ghaffari A, Khounani Z, Roodbar Shojaei T, Mohd Salleh MA. 2017. A novel emulsion fuel containing aqueous nano cerium oxide additive in diesel-biodiesel 
blends to improve diesel engines performance and reduce exhaust emissions: Part I - Experimental analysis. Fuel. 207: 741-750.

Kumar ARM, Kannan M, dan Nataraj G. 2020. A study on performance, emission and combustion characteristics of diesel engine powered by nano-emulsion of waste orange peel oil biodiesel. Renewable Energy. 146: 1781-1795.

Kumar MS dan jaikumar M. 2014. A comprehensive study on performance, emission and combustion behavior of a compression ignition engine fuelled with WCO (waste cooking oil) emulsion as fuel. Journal the Energy Institute. 23(2): 1-9.

Lin C-Y dan Lin S-A. 2007. Effects of emulsification variables on fuel properties of two- and three-phase biodiesel emulsions. Fuel. 86: 2010-2017.

Mahmudul HM, FY Hagos, R Mamat, AA Adam, WFW Ishak \& R Alenezi. 2017. Production, characterization and performance of biodiesel as an alternative fuel in diesel engines - A review. Renewable and Sustainable Energy Reviews. 72: 497-509.

Melo-Espinosa EA, Piloto-Rodríguez R, GoyosPérez L, Sierens R, Verhelst S. 2015. Emulsification of animal fats and vegetable oils for their use as a diesel engine fuel: An overview. Renewable and Sustainable Energy Reviews. 47: 623-633.

Mura E, C Josset, K Loubar, J Bellettre \& P Massoli. 2012. Experimental study of the water in oil emulsions features by differential scanning calorimetry analysis. Applied Energy. 97: 834-840.

Neto AAD, Fernandes MR, Neto ELB, Dantas TNC MCPA Moura. 2011. Alternativ fuel composed by blends of nonionic surfactant with diesel and water: engine performance and emissions. Brazilian Journal Chemical Engineering. 28: 521-531.

Ochoterena R, Li A, Nydén M, Andersson S, Denbratt I. 2010. Optical studies of spray development and combustion of water-indiesel emulsion and microemulsion fuels. Fuel. 89: 122-132.

Phasukarratchai N. 2019. Phase behavior and biofuel properties of waste cooking oil-alcoholdiesel blending in microemulsion form. Fuel. 243: 125-132.

Qi DH, C Bae, YM Feng, Jia CC, \& YZ Bian. 2013. Preparation, characterization, engine combustion and emission characteristics of rapeseed oil based hybrid fuels. Renewable Energy. 60: 98-106.

Qi DH, Chen H, Matthews RD, Bia YZ. 2010. Combustion and emission characteristics of ethanol-biodiesel-water micro-emulsions used in a direct injection compression ignition engine. Fuel. 89: 958-964.

Qiu T, X Guo, J Yang, L Zhou, L Li, H Wang \& Y Niu. 2016. The synthesis of biodiesel from coconut oil using novel Brønsted acidic ionic liquid as green catalyst. Chemical Engineering Journal. 296: 71-78.

Radhakrishnan S, Munuswamy DB, Devarajan Y, Mahalingam A. 2018. Performance, emission and combustion study on neat biodiesel and water blends fuelled research diesel engine. Heat and Mass Transfer. 55(4): 1229-1237.

Ramakrishnan G, P Krishnan, S Rathinam, Devarajan TRY. 2019. Role of nano-additive blended biodiesel on emission characteristics of the research diesel engine. International Journal of Green Energy. 16(6): 435-441.

Reham SS, HH Masjuki, MA Kalam, I Shancita, IM Rizwanul Fattah \& AM Ruhul. 2015. Study on stability, fuel properties, engine combustion, performance and emission characteristics of biofuel emulsion. Renewable and Sustainable Energy Reviews. 52: 1566-1579.

Reyes JSdl \& C Charcosset. 2010. Preparation of water-in-oil and ethanol-in-oil emulsions by membrane emulsification. Fuel. 89: 34823488.

Sadhik Basha J. 2018. Impact of Carbon Nanotubes and Di-Ethyl Ether as additives with biodiesel emulsion fuels in a diesel engine An experimental investigation. Journal of the Energy Institute. 91(2): 289-303.

Sadhik Basha J dan Anand RB. 2011. Role of nanoadditive blended biodiesel emulsion fuel on the working characteristics of a diesel engine. Journal of Renewable and Sustainable Energy. 3(2): 93-106.

Sadhik Basha J dan RB Anand. 2014. Performance, emission and combustion characteristics of a diesel engine using Carbon Nanotubes blended Jatropha Methyl Ester Emulsions. Alexandria Engineering Journal. 53(2): 259-273.

Satapathy D, Sagiri SS, Pal K, Pramanik K. 2013. Development of mustard oil- and groundnut oil-based span 40 organogels as matrices for controlled drug delivery. Designed Monomers and Polymers. 17(6): 545-556.

Sheriff SA, Kumar IK, Mandhatha PS, Jambal SS, Sellappan R, Ashok B, Nanthagopal K. 2020. Emission reduction in CI engine using biofuel reformulation strategies through nano additives for atmospheric air quality improvement. Renewable Energy. 147: 2295-2308. 
Wahyuni S, Hambali E, dan Marbun BTH. 2016. Esterifikasi gliserol dan asam lemak jenuh sawit dengan katalis MESA. Jurnal Teknologi Industri Pertanian. 26(3): 333342.

Tadros Tf. 2013. Emulsion formation, stability, and rheology. Wiley-VCH Verlag $\mathrm{GmbH} \& \mathrm{Co}$. $K G a A$. First edition: 1-73.

Trisunaryanti W, Kartika IA, Mukti RR, Hartati H, Triyono T, Widyawati R, Suarsih E. 2019. Preparation of Ni- and Mo-based catalysts supported on $\gamma$-Al2O3 for hydrocracking of Calophyllum inophyllum oil. Biofuels. 43: 1-6.

Vellaiyan S. 2020. Enhancement in combustion, performance, and emission characteristics of a biodiesel-fueled diesel engine by using water emulsion and nanoadditive. Renewable Energy. 145: 2108-2120.

Vellaiyan S, Subbiah A, dan Chockalingam P. 2018. Combustion, performance, and emission analysis of diesel engine fueled with waterbiodiesel emulsion fuel and nanoadditive. Environ Sci Pollut Res Int. 25(33): 3347833489.

Vellaiyan SA Subbiah dan Chockalingam P. 2019. Multi-response optimization to improve the performance and emissions level of a diesel engine fueled with $\mathrm{ZnO}$ incorporated water emulsified soybean biodiesel/diesel fuel blends. Fuel. 237: 1013-1020.

Vivek P, Abhishek C, Man S, KR K. 2014. Physiochemical and Phase behaviour study of Jatropha curcus oil-ethanol microemulsion fuels using sorbitane fatty esters. Int J Renew Sustain Energy. 3(13): 113.

Wang X, Qin X, Li D, Yang B, Wang Y. 2017. Onestep synthesis of high-yield biodiesel from waste cooking oils by a novel and highly methanol-tolerant immobilized lipase. Bioresour Technol. 235: 18-24.

Xie W dan Wang J. 2014. Enzymatic production of biodiesel from soybean oil by using immobilized lipase on Fe3O4/Poly(styrenemethacrylic acid) Magnetic Microsphere as a Biocatalyst. Energy \& Fuels. 28(4): 26242631.

Yang WM, SKC H. An, S Vedharaji, Vallinagam R, Balaji M, Mohammad FEA, Chua KJE. 2013. Emulsion fuel with novel nanoorganic additiveks for diesel engine application. Fuel. 104: 726-731. 